\title{
Increased expression of both insulin receptor substrates 1 and 2 confers increased sensitivity to IGF-1 stimulated cell migration
}

\author{
Gail E de Blaquière, Felicity E B May and Bruce R Westley
}

The Medical School, Northern Institute for Cancer Research, University of Newcastle upon Tyne, Framlington Place, Newcastle upon Tyne NE2 4HH, UK

(Correspondence should be addressed to F E B May; Email: f.e.b.may @ncl.ac.uk)

\begin{abstract}
Insulin-like growth factors (IGFs) are thought to promote tumour progression and metastasis in part by stimulating cell migration. Insulin receptor substrate-1 (IRS-1) and IRS-2 are multisite docking proteins positioned immediately downstream from the type I IGF and insulin receptors. IRS-2 but not IRS-1 has been reported to be involved in the migratory response of breast cancer cells to IGFs. The purpose of this investigation was to determine if IRS-1 is involved in, and to assess the contributions of IRS-1 and IRS-2 to, the migratory response of breast cancer cells to IGFs. The expression of IRS-1 and IRS-2 varied considerably between ten breast cancer cell lines. Oestrogen increases expression of the type I IGF receptor, IRS-1 and IRS-2 in MCF-7 and ZR-75 cells. Oestrogens may control the sensitivity of breast cancer cells to IGFs by regulating the expression of components of the IGF signal transduction pathway. The migratory response to a range of IGF-1 concentrations was measured in MCF-7 and MDA-MB-231 breast cancer cells in which IRS-1 and IRS-2 levels were modulated using a doxycycline-inducible expression system. Induction of both IRS-1 and IRS-2 expression increased the sensitivity of the migratory response to IGF-1 but did not increase the magnitude of the response stimulated at higher concentrations of IGF-1. Knockdown of IRS-1, IRS-2 and the type I IGF receptor in MCF-7 and MDA-MB-2231 cells decreased sensitivity to IGF-1. We conclude that both IRS-1 and IRS-2 control the migratory response of breast cancer cells to IGF-1 and may, therefore, be key molecules in determining breast cancer spread.
\end{abstract}

Endocrine-Related Cancer (2009) 16 635-647

\section{Introduction}

The insulin-like growth factor (IGF) system comprises two ligands (IGF-1 and IGF-2) as well as the closely related hormone insulin, six binding proteins (IGFBP1-6), three receptors (type I and type II IGF and the insulin receptors) and immediate downstream signalling proteins. The insulin receptor substrate (IRS) proteins act as multisite docking molecules for downstream effectors that have src homology (SH2) domains such as the p85 regulatory subunit of phosphatidylinositol 3 kinase (PI3-kinase) and Shc. Thus, activation of IRS proteins is an early step in various complex signalling cascades that lead to the biological effects of IGFs (Sachdev \& Yee 2001). The IGFs are, as their name suggests, related to insulin.
The structures of the type I IGF and insulin receptors are similar and both are heterotetrameric transmembrane ligand-activated protein tyrosine kinases. The insulin and type I IGF receptors are sufficiently closely related to form hybrid receptors whose signalling characteristics differ from those of the parent receptors (Pandini et al. 1999). The type I IGF receptor binds IGF-1 and IGF-2 with high affinity and insulin with lower affinity.

The IGFs were discovered as a result of their key roles in juvenile growth and development. The major source of circulating IGFs is the liver and their synthesis is controlled by GH. The IGFs are also synthesised at extrahepatic sites where they act as paracrine and autocrine growth factors. 
IGFs have been implicated in the aetiology and progression of a variety of cancers (Pollak 2000). Elevated circulating levels of IGF-1 together with decreased concentrations of IGFBP3, the protein to which it is bound in the circulation, are a significant risk factor for breast (Hankinson et al. 1998, Davies et al. 2006, Schernhammer et al. 2005), colon (Davies et al. 2006) and prostate cancer (Chan et al. 1998). Over expression of components of the IGF system such as the type I IGF receptor and IRS-1 and IRS-2 are characteristic of some cancers and can result in cell transformation in experimental systems (D'Ambrosio et al. 1995, Guvakova \& Surmacz 1997, Chang et al. 2002). In addition, there is evidence that elevated IRS-1 expression is associated with a poor prognosis in breast cancer (Rocha et al. 1997).

The normal biological properties of IGFs are thought to be subverted by cancer cells to facilitate tumour progression. IGFs are mitogenic for a large number of cell types including breast cancer cells (Stewart et al. 1990, Daws et al. 1996), they inhibit apoptosis induced by a variety of agents including staurosporine and ceramide (Peruzzi et al. 1999, Kooijman 2006) and they increase cell migration and invasion (Doerr \& Jones 1996, Bartucci et al. 2001). All of these properties are required for the growth and metastasis of tumour cells (Baserga 2004).

On the basis of a large amount of biological data, the IGF system is emerging as a credible therapeutic target in cancer (Baserga 2004, Yee 2006). A number of strategies are in development of which the most important are inhibition of the binding of IGF to the receptor and down regulation of the type I IGF receptor by anti-receptor antibodies (Li et al. 2000, Hailey et al. 2002, Maloney et al. 2003, Sachdev et al. 2003, Wang et al. 2005) and inhibition of the receptor tyrosine kinase (Stromberg et al. 2006, Tazzari et al. 2007).

In breast cancer, lifetime exposure to oestrogens is a principal risk factor (Eliassen et al. 2006) and the oestrogen receptor (ER) is an important therapeutic target as exemplified by the development and widespread therapeutic use of oestrogen antagonists (Wickerham 2002) and aromatase inhibitors (Altundag \& Ibrahim 2006). The mechanisms by which oestrogens control breast cancer progression are not completely understood but the genomic effects of oestrogens whereby they control the expression of a limited repertoire of genes are of major importance (Westley \& May 2006). We (Stewart et al. 1990, Daws et al. 1996) and others (Lee et al. 1999, Mauro et al. 2001, Bernard et al. 2006) have shown that oestrogens increase the responsiveness of breast cancer cells to IGFs and that they regulate the expression of key components of the IGF signal transduction pathway including IGF-2 (Westley et al. 1998) the type I IGF receptor (Stewart et al. 1990) and IRS-1 (Molloy et al. 2000). This has led to the concept that oestrogens may act, at least in part, through increasing the responsiveness of breast cancer cells to IGFs.

The stimulation of breast cancer cell migration by IGFs may be one mechanism by which oestrogens promote tumour progression. The motogenic effects of IGFs have, however, been somewhat controversial. Bae et al. (1993) concluded that the MCF-7 cell line which expresses relatively high levels of the type-1 IGF receptor has a non-invasive phenotype while Pennisi et al. (2002) implicated the type-1 IGF receptor in cell migration but found that receptor expression is inversely related to cell migration. Jackson et al. (2001) showed that IGF-1 stimulated the migration of a metastatic variant of MDA-MB-231 cells but not the parental cells. By contrast, Doerr \& Jones (1996), Bartucci et al. (2001) and Byron et al. (2006) showed that IGFs do stimulate the migration of breast cancer cell lines. One aim of this study therefore was to determine whether IGFs stimulate breast cancer cell migration and we conclude that there is a concentration dependent increase in cell migration in both MCF-7 and MDA-MB-231 cell lines.

Recent studies have reported distinct roles for IRS-1 and IRS-2 in breast cancer and suggested that IRS-1 regulates cell proliferation whereas IRS-2 regulates cell migration (Jackson et al. 2001, Byron et al. 2006, Gibson et al. 2007). In the present study, we examine the possible role of IRS proteins in mediating the effects of oestrogen on breast cancer cell invasion by increasing specifically IRS- 1 or IRS-2 expression in breast cancer cells using a tetracycline-inducible expression system. Notably, we show that IRS-1 as well as IRS-2 can increase cell migration. This focuses attention on both IRS-1 and IRS-2 as a convergence point of oestrogen and IGF signalling and as potential therapeutic targets for the treatment of hormone responsive and non-responsive breast cancer.

\section{Materials and methods}

\section{Cell culture}

MCF-7 cells, their derivatives and all other breast cell lines, ZR-75, T-47D, EFF-3, EFM-19, BT 20, Hs 578T, SK-BR-3 and HBL-100, apart from MDA-MB231 were cultured routinely in DMEM containing $10 \%$ FCS and $1 \mu \mathrm{g} / \mathrm{ml}(0.17 \mu \mathrm{M})$ insulin. MDA-MB-231 cells and derivatives were cultured in DMEM containing 5\% FCS and $1 \mu \mathrm{g} / \mathrm{ml}(0.17 \mu \mathrm{M})$ insulin. 


\section{Preparation of stable pTet-on cell lines}

MCF-7 cells, stably transfected with the pTet-on plasmid, were purchased from BD Clontech. MDAMB-231 cells stably transfected with the pTet-on plasmid were created using liposome-mediated transfection (Clonfectin, BD Clontech) and selection in $400 \mu \mathrm{g} / \mathrm{ml} \mathrm{G} 418$. Clones were transiently transfected with the pTRE2-luc plasmid (BD Clontech) using liposome-mediated transfection and the clone with the highest induction of luciferase by doxycycline and the lowest background was used in subsequent experiments.

\section{Cloning of the IRS-1 and IRS-2 cDNA into the pTRE2 response plasmid}

The human IRS-1 (Sun et al. 1991) and IRS-2 (Vassen et al. 1999) mRNA sequences were excised from the recombinant plasmids, purified on a low melting agarose gel and then ligated to pTRE2 plasmid (BD Clontech). Recombinant plasmids were sequenced to confirm the correct sequence and orientation of the cDNA.

\section{Creation of Tet-on cells stably transfected with recombinant $\mathrm{pTRE} 2$ plasmids}

MCF-7 Tet-on and MDA-MB-231 Tet-on cells were co-transfected with the recombinant pTRE2 plasmids and pTKhyg which confers resistance to hygromycin. Stably transfected cell lines were selected by culture in hygromycin B. The expression of IRS-1 and IRS-2 was measured in the transfected MCF-7 and MDA-MB-231 cells following culture in the presence of doxycycline for $48 \mathrm{~h}$ in three separate experiments. IRS-1 expression was increased threefold $(3 \pm 0.5)$ and IRS-2 expression fivefold $(5 \pm 0.4)$ in MCF-7 cells, whereas IRS-1 was increased fourfold $(4 \pm 0.6)$ and IRS-2 expression sevenfold ( $7 \pm 0.7)$ in MDA-MB-231 cells. The expression of the type I IGF receptor and insulin receptor in MCF-7 and MDA-MB-231 cells transfected with pTRE2 plasmid, pTRE2 IRS-1 plasmid or pTRE2 IRS-2 plasmid was not affected by treatment with $50 \mathrm{ng} / \mathrm{ml}(6.5 \mathrm{nM})$ IGF-1, $50 \mathrm{ng} / \mathrm{ml}(8.5 \mathrm{nM})$ insulin or $1 \mu \mathrm{g} / \mathrm{ml}(0.17 \mathrm{mM})$ insulin (data not shown).

\section{Measurement of type I IGF receptor, IRS-1 and IRS-2 proteins by western transfer}

Lysates were prepared either from cells growing in normal culture medium or from cells that had been stimulated with combinations of $17 \beta$-oestradiol and IGF-1. For the latter, cells were grown in T25 flasks until $\sim 60 \%$ confluent, washed twice with PBS and cultured for 6 days in phenol red-free DMEM supplemented with 10\% charcoal-treated newborn calf serum. The medium was changed every $24 \mathrm{~h}$. To study the effects of oestrogen, cells were cultured for an additional 2 days in the above medium or medium supplemented with the combinations of $10 \mathrm{nM}$ oestrogen, $50 \mathrm{ng} / \mathrm{ml}(6.5 \mathrm{nM})$ IGF-1 and $1 \mu \mathrm{g} / \mathrm{ml}(0.17 \mu \mathrm{M})$ insulin for $48 \mathrm{~h}$. After $48 \mathrm{~h}$, cells were washed with ice-cold PBS, and lysed using RIPA buffer containing a cocktail of protease and phosphatase inhibitors. The lysate was centrifuged at $12000 \mathrm{~g}$ at $4{ }^{\circ} \mathrm{C}$ for $10 \mathrm{~min}$, the supernatant removed and stored frozen. Protein concentrations were measured using the bicinchoninic acid assay (Pierce Protein Research Products, Thermo Fisher Scientific Inc., Rockford, IL, USA) with BSA as the standard. Expression was evaluated in a minimum of three experiments that were analysed at least twice and in each case a representative result is shown in the figures for illustrative purposes.

Cell lysate proteins were separated on a 9 or $10 \%$ acrylamide separating gel or on a gradient polyacrylamide gel with a $3 \%$ acrylamide stacking gel and transferred to nitrocellulose. The nitrocellulose filters were blocked using tris-buffered saline containing 5\% milk and $0.1 \%$ Tween 20 (TBST-milk) for $1 \mathrm{~h}$ at room temperature and then incubated overnight with anti IRS-1 (1:1000-1:5000), anti IRS-2 (1:500-1:1000), anti type I IGF receptor $(1: 1000-1: 4000)$ or anti GAPDH (1:6000-1:20 000) in TBST-milk overnight at $4{ }^{\circ} \mathrm{C}$. The antibodies were from Upstate, Millipore, Billerica, MA, USA (IRS-1, 06-248; IRS-2, 06-506), Santa Cruz Biotechnology Inc., Santa Cruz, CA, USA (IRS-1 sc-7200; IRS-2, sc-1555-R; GAPDH, sc-25778) and Cell Signaling Technology Inc., Boston, MA, USA (type I IGF receptor, 3027). The filters were washed four times in TBST and incubated in HRP-conjugated goat-anti-rabbit antibody (1:2000) and the proteins detected using enhanced chemiluminescence (Western Dura Super Signal extended duration substrate, Pierce). Protein expression was quantified by densitometric analysis of the resultant X-ray films and the optical density analysed with Labworks 4 software (Ultraviolet Products, Cambridge, UK). Data were normalised by reference to expression of GAPDH.

\section{Measurement of cell migration}

Insulin binds to and stimulates auto-phosphorylation of the type I IGF receptor. The medium used for the routine culture of breast cancer cell lines contains insulin at a concentration high enough $(1 \mu \mathrm{g} / \mathrm{ml}$, $0.17 \mu \mathrm{M})$ to stimulate the type I IGF receptor. We were therefore concerned that the migration of cells 
may be affected by the culture conditions and in particular that it could be affected by the removal of ligands for the type I IGF receptor prior to the migration assay. The response to IGF-1 was therefore measured in cells grown in the absence or presence of IGF-1 for the $48 \mathrm{~h}$ prior to the migration assay (data not shown). There were no statistically significant differences between the responses of cells cultured in the presence or absence of IGF-1 for $48 \mathrm{~h}$ prior to the migration assay and cells were cultured in the absence of IGF-1 in all subsequent experiments.

Cells were grown in T25 flasks until $\sim 30 \%$ confluent, washed twice with PBS and cultured for $48 \mathrm{~h}$ in phenol red-free DMEM supplemented with $10 \%$ charcoal-treated newborn calf serum in the presence or absence of doxycycline $(2 \mu \mathrm{g} / \mathrm{ml})$. Cells were trypsinised after $48 \mathrm{~h}$ and $1.5 \times 10^{4}$ cells added to the upper chamber of a micro chemotaxis chamber in $50 \mu \mathrm{l}$ of phenol red-free DMEM containing $0.01 \%$ BSA. The upper and lower chambers were separated by an $8 \mu \mathrm{m}$ pore membrane that had been coated with collagen IV for $45 \mathrm{~min}$ at room temperature. The bottom chamber contained phenol red-free DMEM supplemented with $0.01 \%$ BSA containing varying concentrations of IGF-1 $(0-50 \mathrm{ng} / \mathrm{ml} ; 0-6.5 \mathrm{nM})$. The response to each concentration of IGF-1 was tested in triplicate assays in each experiment. The chamber was incubated for $5 \mathrm{~h}$ (MDA-MB-231 and derivatives) or $6 \mathrm{~h}$ (MCF-7 and derivatives) at $37{ }^{\circ} \mathrm{C}$ in a cell culture incubator. The chamber was then dismantled, cells scraped from the upper surface and the migrated cells attached to the lower surface, by fixation in methanol for $5 \mathrm{~min}$. The cells were stained with haematoxylin for 5 min, the filter washed under running tap water and in Scott's tap water for $5 \mathrm{~min}$ and then mounted on glass slides with the migrated cells on the uppermost surface. Cell migration was quantified by counting the migrated cells in five fields at 400-fold magnification in each of the triplicate assays (Prest et al. 2002).

\section{Knockdown of type I IGF receptor, IRS-1 and IRS-2}

MCF-7 and MDA-MB-231 cells were transfected with empty vector, or siRNA plasmids: pKD-IGF-IR-v2; pKD-IRS1-v3 or pKD-IRS2-v4 (Upstate) in the presence of FuGENE HD transfection reagent (Roche) at different ratios as recommended by the manufacturer. After 18-24 h, cells were lysed or the medium was replaced with routine culture medium. Thereafter, the medium was changed daily and cells were lysed at daily intervals. Aliquots of protein lysate were analysed by western transfer for expression of the type I IGF receptor, IRS-1 or IRS-2. Optimal knockdown to $10-20 \%$ of the expression of the proteins in the control transfected cells was obtained after 2-3 days in MCF-7 cells and after 2-3 days in MDA-MB-231 cells.

To test the effects of the knockdown on migration, cells were grown to $20-30 \%$ confluence in T25 flasks, washed with PBS and transfected with the siRNA plasmids at a 3:1 ratio of FuGENE HD to DNA. After 18-24 h, the cells were washed twice with PBS and the medium was replaced with phenol red-free DMEM supplemented with $10 \%$ charcoal-treated newborn calf serum and the cells were cultured for $24 \mathrm{~h}$. The migration response of MDA-MB-231 cells was tested at this stage but MCF-7 cells were washed twice with PBS and the medium was replaced with phenol red-free DMEM supplemented with $10 \%$ charcoal-treated newborn calf serum and cultured for a further $24 \mathrm{~h}$ at which time the migration response was measured essentially as described above. Concentrations of IGF-1 between 0 and $100 \mathrm{ng} / \mathrm{ml}(0-13 \mathrm{nM})$ were tested, the chambers were incubated for $4-4.5 \mathrm{~h}$ and the non-migrated cells were allowed to remain on the filters.

\section{Statistical analysis}

Differences between groups were tested by ANOVA, paired or unpaired $t$-test and Mann-Whitney test.

\section{Results}

\section{Expression of IRS-1 and IRS-2 in human breast cancer cell lines}

IRS-1 and IRS-2 expression was measured by western transfer analysis in a panel of 10 human breast cancer cell lines comprising five oestrogen responsive (MCF-7, T-47D, ZR-75-1, EFM-19, EFF-3) and five oestrogen non-responsive lines (HBL-100, Hs 578T, MDA-MB-231, SK-BR-3 and BT 20; Fig. 1A and B) that had been cultured in normal growth medium. The levels of expression of both proteins varied by approximately two orders of magnitude in the ten cell lines. Expression of IRS-1 was highest in the oestrogen non-responsive Hs 578T cell line whereas expression of IRS-2 was highest in the oestrogen nonresponsive MDA-MB-231 cell line.

\section{Effect of IGF-1 on cell migration}

The effects of different concentrations of IGF-1 were tested on cell migration in both MCF-7 and MDA-MB-231 cells that had been stably transfected with the pTet-on plasmid alone (Fig. 2). The effect of IGF-1 on cell migration was tested on cells that had 

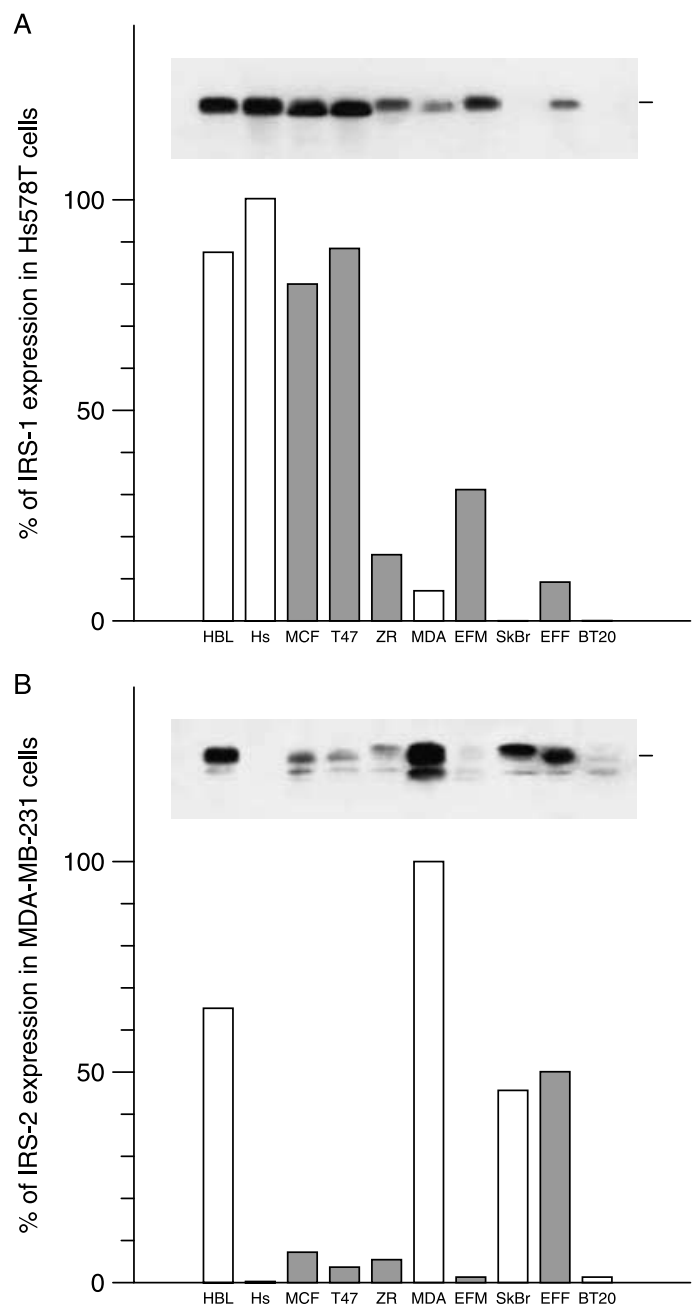

Figure 1 Expression of IRS-1 and IRS-2 in human breast cancer cells. HBL-100 (HBL); Hs578T (Hs); MCF-7 (MCF); T-47D (T47); ZR-75 (ZR); EFM-19 (EFM); Sk-Br-3 (SkBr); EFF-3 (EFF) and BT 20 (BT20) cells were grown in DMEM containing $10 \% \mathrm{FCS}$ and $1 \mu \mathrm{g} / \mathrm{ml}$ insulin. MDA-MB-231 (MDA) cells were grown in DMEM containing $5 \%$ FCS and $1 \mu \mathrm{g} / \mathrm{ml}$ insulin. The cells were lysed and protein extracts prepared as described in the Materials and methods. The amounts of IRS-1 (A) and IRS-2 (B) were measured in these oestrogen responsive and non-responsive breast cell lines by western transfer analysis as described in the Materials and methods. Aliquots of $10 \mu \mathrm{g}$ protein were electrophoresed on $9 \%$ polyacrylamide gels and transferred to nitrocellulose membranes. The membranes were incubated with specific IRS-1 antibody (Upstate 06-248) or specific IRS-2 antibody (Upstate 06-506) overnight at $4{ }^{\circ} \mathrm{C}$, HRP-conjugated goatanti-rabbit antibody and the proteins detected using enhanced chemiluminescence (Western Dura Super Signal extended duration substrate, Pierce). The amount of each protein was determined by densitometric scanning of X-ray films followed by analysis with Labworks 4 software as described in the Materials and methods. The amount of each protein was expressed as the percentage of the amount of protein in the cell line expressing the most protein and is represented in the histogram. The filled and unfilled columns indicate the expression in oestrogen-responsive and oestrogen non-responsive cell lines respectively.

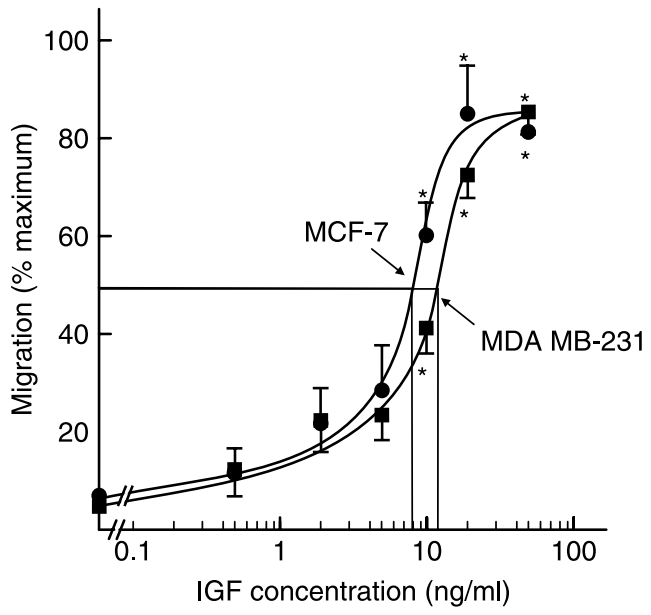

Figure 2 Effect of IGF-1 on cell migration of MCF-7 and MDA-MB-231 cells. MCF-7 and MDA-MB-231 cells were cultured for $48 \mathrm{~h}$ in phenol red-free DMEM supplemented with $10 \%$ charcoal-treated newborn calf serum. Cells were trypsinised after $48 \mathrm{~h}$, washed and $1.5 \times 10^{4}$ cells added to the upper chamber of a micro chemotaxis chamber in $50 \mu$ phenol red-free DMEM containing $0.01 \%$ BSA. The bottom chambers contained different concentrations of IGF-1 in $30 \mu \mathrm{l}$ phenol red-free DMEM containing $0.01 \%$ BSA. Squares show the migration of MDA-MB-231 cells and circles the migration of MCF-7 cells stimulated by different concentrations of IGF-1 and analysed as described in the Materials and methods. The bars show the S.E.M. of measurements from four separate experiments. In both cell lines, IGF-1 stimulated migration at and above $10 \mathrm{ng} / \mathrm{ml}(1.3 \mathrm{nM})$. Asterisks show migration that is statistically significantly higher than in control cells for each cell line using ANOVA (10 ng/ml $(1.3 \mathrm{nM})$ and above, $P<0.05)$. The MCF-7 Tet-on cells show significantly more migration than MDAMB-231 Tet-on cells at $10 \mathrm{ng} / \mathrm{ml}(1.3 \mathrm{nM})$ IGF-1 ( $t$-test, $P=0.01)$.

been cultured in the absence of insulin for two days. The migration of the MCF-7 cells was increased approximately tenfold by IGF-1. The increase was concentration dependent with a half maximal increase at $8 \mathrm{ng} / \mathrm{ml}(1.04 \mathrm{nM})$. The effect of IGF-1 on the migration of the MDA-MB-231 cells was tested using the same culture conditions. IGF-1 increased MDA-MB-231 cell migration approximately tenfold with half maximal stimulation at a concentration of $12 \mathrm{ng} / \mathrm{ml}(1.62 \mathrm{nM})$. While the magnitude of the effect of IGF-1 on migration in the two cell lines was similar, the stimulation at $10 \mathrm{ng} / \mathrm{ml}(1.3 \mathrm{nM})$ IGF-1 was significantly $(P=0.048)$ greater in MCF-7 Tet-on cells than in MDA-MB-231 Tet-on cells.

\section{Effects of oestrogen, IGF-1 and insulin on the induction of type I IGF receptor, IRS-1 and IRS-2 in oestrogen-responsive breast cancer cells}

IGF-1 is a high-affinity ligand whereas insulin is a low-affinity ligand for the type I IGF receptor. The effects of oestrogen in the absence and presence of 
IGF-1 and insulin on the expression of the type I IGF receptor, IRS-1 and IRS-2 were measured in two oestrogen-responsive breast cancer cell lines to assess the induction by oestrogen and the effects of insulin and IGF-1 on the oestrogen induction (Fig. 3). The effects of oestrogen were tested also in the MDA-MB231 oestrogen non-responsive cell line. The type I IGF receptor antibody detected two bands; a minor band of $\sim 165 \mathrm{kDa}$ which corresponds most probably to the proprotein of the type I IGF receptor and a major band of $95 \mathrm{kDa}$ corresponding to the processed $\beta$-subunit. Oestrogen induced expression of the type I IGF receptor in the absence and presence of IGF-1 and insulin and there was no synergistic effect of oestrogen with either type I IGF receptor ligand. The expression of the type I IGF receptor was greater in MCF-7 than in ZR-75 cells but its induction by oestrogen was more marked in ZR-75 cells.

IRS-1 was induced dramatically by oestrogen in both MCF-7 and ZR-75 cells. It was expressed at higher levels in oestrogen-treated MCF-7 cells. In
MCF-7 cells, IRS-1 induction was greater in the presence of IGF-1 and insulin than with oestrogen alone and insulin and IGF-1 increased IRS- 1 slightly in the absence of oestrogen. IRS-2 was induced by oestrogen in both MCF-7 cells and ZR-75 cells and induction was greater in ZR-75 cells. IGF-1 and insulin decreased slightly IRS-2 expression in the absence of oestrogen in ZR-75 cells, therefore the induction by oestrogen was greater in their presence in this cell line. Oestrogen had no effect on the expression of the type I IGF receptor, IRS-1 or IRS-2 in MDA-MB231 cells.

The induction by oestrogen of the type I IGF receptor, IRS-1 and IRS-2 varies with the cell line and culture conditions as shown previously for other oestrogen responsive genes (Clayton et al. 1997, Donaghue et al. 1999, Westley \& May 2006). These experiments show, however, that these key components of the IGF signal transduction pathway are all induced by oestrogen in both oestrogen-responsive breast cancer cell lines.

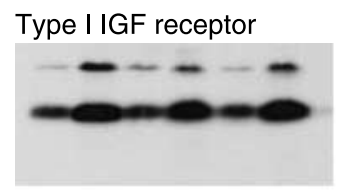

IRS-1

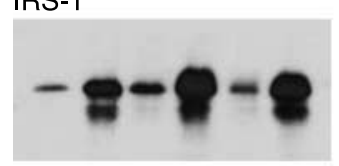

IRS-2

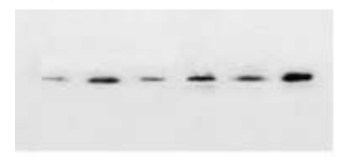

GAPDH

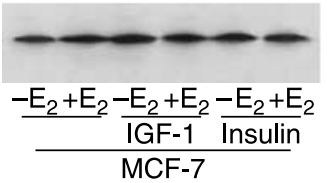

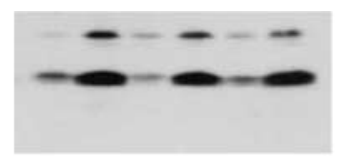
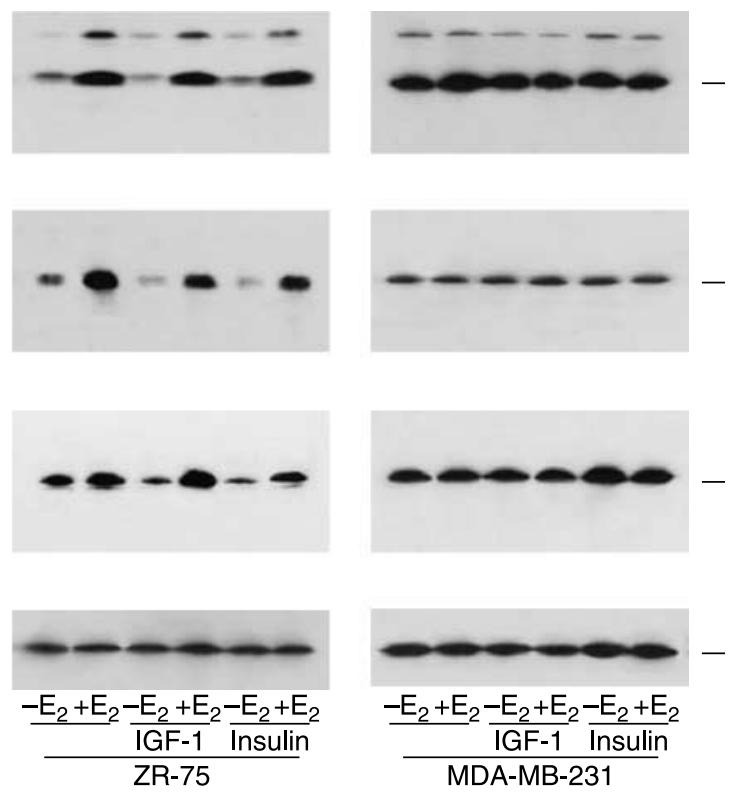

Figure 3 Effect of oestrogen on the expression of the type I IGF receptor, IRS-1 and IRS-2 in oestrogen-responsive breast cancer cells. MCF-7 and ZR-75 oestrogen-responsive breast cancer cells and MDA-MB-231 oestrogen non-responsive breast cancer cells were withdrawn from hormones present in routine culture medium and treated with oestradiol $\left(\mathrm{E}_{2}, 10 \mathrm{nM}\right)$ either alone or in the presence of IGF-1 $(50 \mathrm{ng} / \mathrm{ml} ; 6.5 \mathrm{nM})$ or insulin $(1 \mu \mathrm{g} / \mathrm{ml} ; 0.17 \mu \mathrm{M})$ for $48 \mathrm{~h}$. The cells were lysed and protein extracts prepared as described in the Materials and methods. The amounts of type I IGF receptor, IRS-1 and IRS-2 were measured by western transfer analysis as described in the Materials and methods. Aliquots of $20 \mu \mathrm{g}$ protein were electrophoresed on $10 \%$ polyacrylamide gels and transferred to nitrocellulose membranes. The membranes were incubated with specific type I IGF receptor antibody (Cell Signalling, 3027), specific IRS-1 antibody (Upstate 06-248), specific IRS-2 antibody (Santa Cruz, sc-1555-R) or specific GAPDH antibody (Santa Cruz, sc-25778) overnight at $4{ }^{\circ} \mathrm{C}$. The membranes were washed and incubated with HRP-conjugated goat-anti-rabbit antibody and the proteins detected using enhanced chemiluminescence (Western Dura Super Signal extended duration substrate, Pierce). The relative amounts of each protein were determined by densitometric scanning of X-ray films followed by analysis with Labworks 4 software as described in the Materials and methods. 


\section{Transfection of breast cancer cell lines with inducible IRS-1 and IRS-2 expression vectors}

One oestrogen responsive and one oestrogen nonresponsive breast cancer cell line was transfected with an inducible IRS-1 or IRS-2 expression construct to examine the importance of IRS-1 and IRS-2 on stimulation of cell migration by IGF-1. The Tet-on system, in which expression is induced by doxycycline, was used for these experiments.
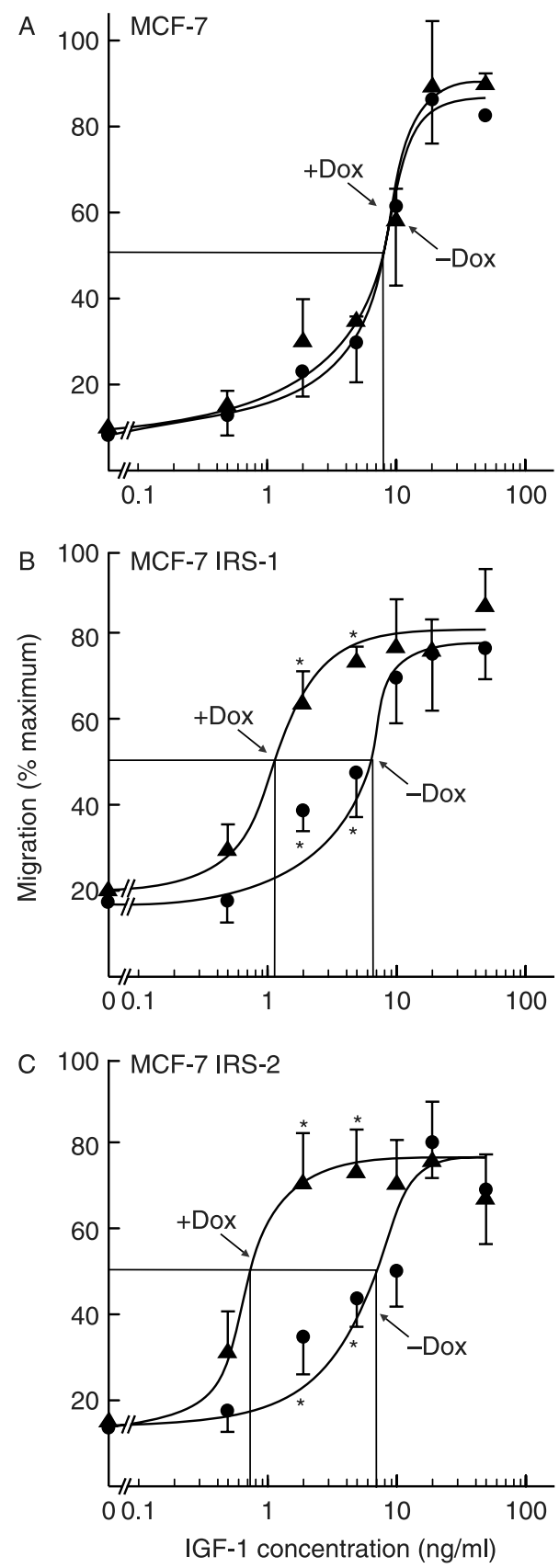

Recombinant pTRE2 plasmids containing the entire coding region of human IRS-1 (Sun et al. 1991) and IRS-2 (Vassen et al. 1999) were constructed as described in the Materials and methods. These plasmids were stably transfected into MCF-7 and MDA-MB-231 Tet-on cells. The expression of IRS-1 and IRS-2 was measured in the transfected MCF-7 and MDA-MB-231 cells following culture in the presence of doxycycline for $48 \mathrm{~h}$. IRS-1 expression was increased approximately threefold and IRS-2 expression fivefold in MCF-7 cells, whereas IRS-1 was increased fourfold and IRS-2 expression sevenfold in MDA-MB-231 cells (data not shown).

\section{Effect of increased expression of IRS-1 and IRS-2 on MCF-7 cell migration}

The effect of increased expression of IRS-1 and IRS-2 on IGF-stimulated migration was measured in cells that had been cultured in the absence or presence of $2 \mu \mathrm{g} / \mathrm{ml}$ doxycycline for $48 \mathrm{~h}$. Doxycycline had no effect in MCF-7 Tet-on cells (Fig. 4A). Cell migration was increased approximately tenfold and the concentration of IGF-1 required for half-maximal cell migration was $8 \mathrm{ng} / \mathrm{ml}$ in the presence and absence of doxycycline.

By contrast, the response of MCF-7 IRS-1 and MCF-7 IRS-2 cells to IGF-1 was altered by treatment with doxycycline. For both cell lines, the number of migrated cells at higher concentrations of IGF-1 was not altered but the concentration of IGF-1 required for

Figure 4 Effect of increased expression of IRS-1 and IRS-2 in MCF-7 cells on IGF-1 stimulated cell migration. MCF-7 cells transfected with pTRE2 (A), pTRE2 IRS-1 (B) and pTRE2 IRS-2 (C) were cultured in the absence and presence of doxycycline and the migration in response to different concentrations of IGF-1 was measured as described in the legend to Fig. 2. Circles show cell migration after culture in the absence of doxycycline, whereas triangles show cell migration after culture in the presence of doxycycline. The bars show the S.E.M. of at least three experiments. Asterisks show the concentrations at which migration is statistically significantly higher in the cells that had been cultured in the presence of doxycycline ( $t$-test, $P=0.04$ at $2 \mathrm{ng} / \mathrm{ml} ; 0.26 \mathrm{nM}, P=0.03$ at $5 \mathrm{ng} / \mathrm{ml} ; 0.65 \mathrm{nM}$ for both MCF-7 IRS-1 and IRS-2) than in cells that had been cultured in the absence of doxycyline. The migration was statistically higher in cells stimulated with IGF-1 than in unstimulated cells at IGF-1 concentrations of $20 \mathrm{ng} / \mathrm{ml} ; 2.6 \mathrm{nM}$ and above for MCF-7 cells that had been cultured in the absence of doxycyline, $10 \mathrm{ng} / \mathrm{ml} ; 1.3 \mathrm{nM}$ and above for MCF-7 cells that had been cultured in the presence of doxycycline, $10 \mathrm{ng} / \mathrm{ml} ; 1.3 \mathrm{nM}$ and above for MCF-7 IRS-1 cells that had been cultured in the absence of doxycyline, $2 \mathrm{ng} / \mathrm{ml}$; $0.26 \mathrm{nM}$ and above for MCF-7 IRS- 1 cells that had been cultured in the presence of doxycycline, $20 \mathrm{ng} / \mathrm{ml} ; 2.6 \mathrm{nM}$ and above for MCF-7 IRS-2 cells that had been cultured in the absence of doxycyline and $2 \mathrm{ng} / \mathrm{ml} ; 0.26 \mathrm{nM}$ and above for MCF-7 IRS-2 cells that had been cultured in the presence of doxycycline (ANOVA, $P<0.05$ ). 
half-maximal stimulation of cell migration was reduced (Fig. 4B and C). This shows that increased IRS-1 and IRS-2 expression increases sensitivity to IGF-1 stimulated migration. For MCF-7 IRS-1 cells, this was approximately sixfold (from 6.5 to $1.1 \mathrm{ng} / \mathrm{ml}$ ) whereas for MCF-7 IRS-2 cells it was approximately tenfold (from 7 to $0.7 \mathrm{ng} / \mathrm{ml}$ ).
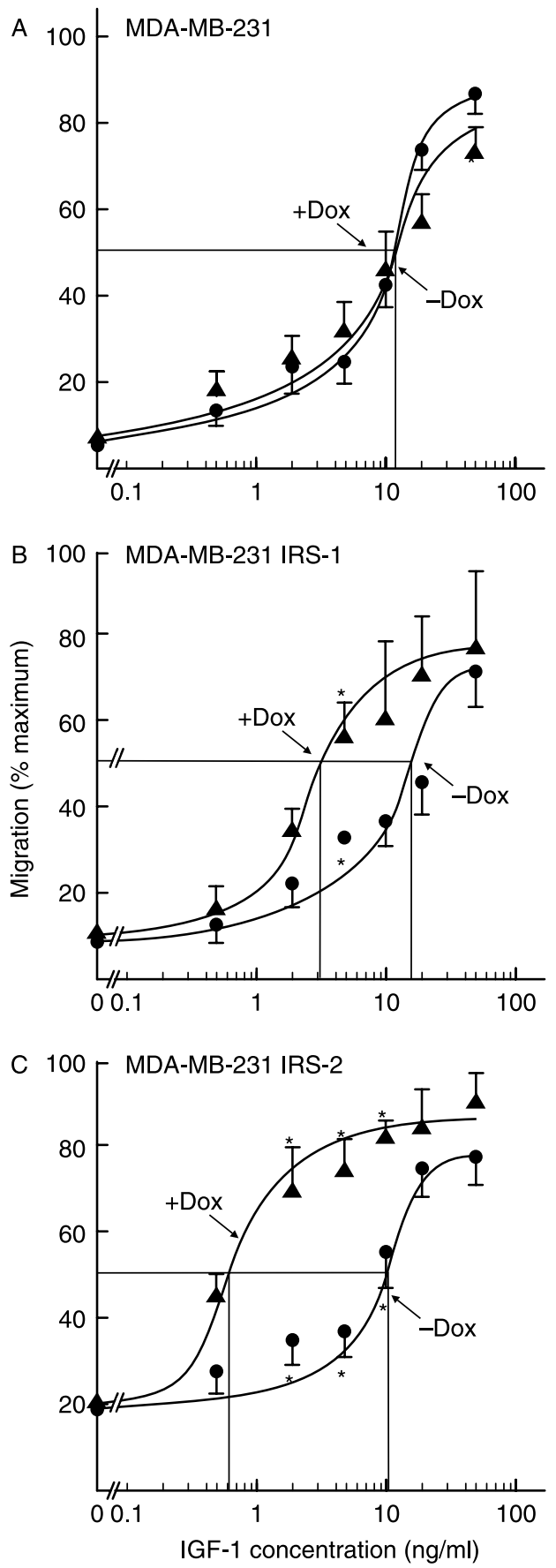

\section{Effect of increased expression of IRS-1 and IRS-2 on MDA-MB-231 cell migration}

The effect of increasing the expression of IRS-1 and IRS- 2 on IGF-1 stimulated cell migration was tested by culturing the transfected MDA-MB-231 cells for $48 \mathrm{~h}$ in $2 \mu \mathrm{g} / \mathrm{ml}$ doxycycline. Doxycycline had no effect on the parental MDA-MB-231 Tet-on cells (Fig. 5A). Cell migration was increased approximately tenfold and the concentration of IGF-1 required for half-maximal cell migration was $12 \mathrm{ng} / \mathrm{ml}$ in the absence and presence of doxycycline.

By contrast, the response of MDA-MB-231 IRS-1 (Fig. 5B) and MDA-MB-231 IRS-2 (Fig. 5C) cells to IGF-1 was altered by prior treatment with doxycycline. The number of migrated cells at higher concentrations of IGF-1 was not altered but the concentration of IGF-1 required for half-maximal stimulation of cell migration was reduced. This shows that, as for MCF-7 cells, IRS-1 and IRS-2 expression increases sensitivity to IGF-1. For MDA-MB-231 IRS-1 cells this was approximately sixfold (from 17 to $3 \mathrm{ng} / \mathrm{ml}$ ) whereas for MDA-MB-231 IRS-2 cells it was $\sim 17$-fold (from 10.5 to $0.6 \mathrm{ng} / \mathrm{ml}$ ).

\section{Effect of decreased expression of IRS-1 and IRS-2 on MCF-7 and MDA-MB-231 cell migration}

The effect of decreasing the expression of the type I IGF receptor, IRS-1 and IRS-2 on IGF-1 stimulated cell migration was tested in MCF-7 and MDA-MB-231 cells in which expression had been knocked down by transfection of the cells with siRNA plasmids as

Figure 5 Effect of increased expression of IRS-1 and IRS-2 on IGF-1 stimulated cell migration in MDA-MB-231 cells. MDA-MB-231 cells transfected with pTRE2 (A), pTRE2 IRS-1 (B) and pTRE2 IRS-2 (C) were cultured in the absence and presence of doxycycline and the migration in response to different concentrations of IGF-1 was measured as described in the legend to Fig. 2. Circles show cell migration after culture in the absence of doxycycline, whereas triangles show cell migration after culture in the presence of doxycycline. The bars show the S.E.M. of at least three experiments. Asterisks show the concentrations at which migration is statistically significantly higher in the cells that had been cultured in the presence of doxycycline ( $t$-test, $P=0.04$ at $5 \mathrm{ng} / \mathrm{ml} ; 0.65 \mathrm{nM}$ for MDA-MB-231 IRS-1 and $P=0.047$ at $2 \mathrm{ng} / \mathrm{ml} ; 0.26 \mathrm{nM}, P=0.015$ at $5 \mathrm{ng} / \mathrm{ml} ; 0.65 \mathrm{nM}$ and $P=0.014$ at $10 \mathrm{ng} / \mathrm{ml} ; 1.3 \mathrm{nM}$ for MDA-MB-231 IRS-2 than in cells that had been cultured in the absence of doxycyline. The migration was statistically higher in cells stimulated with IGF-1 than in unstimulated cells at concentrations of $10 \mathrm{ng} / \mathrm{ml} ; 1.3 \mathrm{nM}$ and above for MDA-MB-231 cells that had been cultured in the absence and presence of doxycycline, $50 \mathrm{ng} / \mathrm{ml} ; 6.5 \mathrm{nM}$ for MDAMB-231 IRS-1 cells that had been cultured in the absence of doxycyline, $20 \mathrm{ng} / \mathrm{ml}$; $2.6 \mathrm{nM}$ and above for MDA-MB-231 IRS-1 cells that had been cultured in the presence of doxycycline, $20 \mathrm{ng} / \mathrm{ml} ; 2.6 \mathrm{nM}$ and above for MDA-MB-231 IRS-2 cells that had been cultured in the absence of doxycyline and $2 \mathrm{ng} / \mathrm{ml} ; 0.26 \mathrm{nM}$ and above for MDA-MB-231 IRS-2 cells that had been cultured in the presence of doxycycline (ANOVA, $P<0.05$ ). 


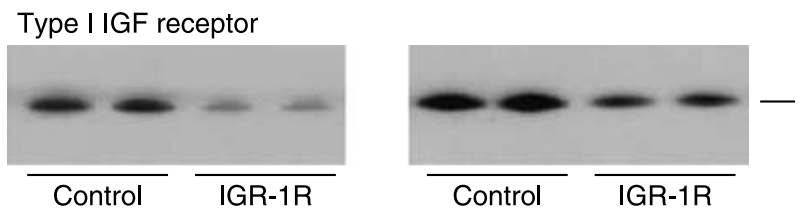

IRS-1

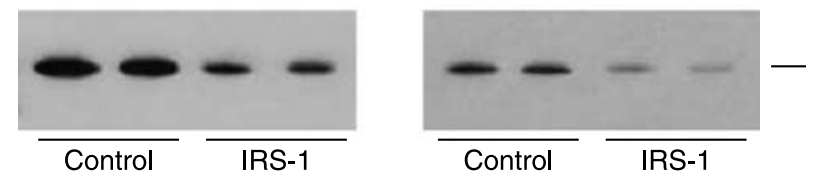

IRS-2

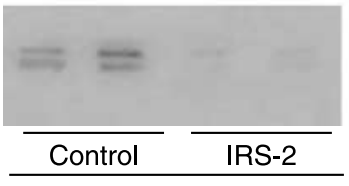

MCF-7

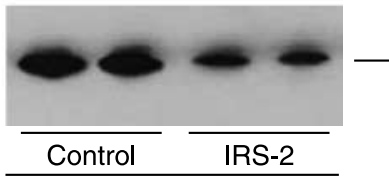

MDA-MB-231

Figure 6 Expression of the type I IGF receptor, IRS-1 and IRS-2 in breast cancer cells transfected with pKD-IGF-IR; pKD-IRS1 or pKD-IRS2. MCF-7 and MDA-MB-231 cells were transfected with siRNA plasmids: pKD-IGF-IR-v2 (IGF-IR); pKD-IRS1-v3 (IRS-1) or pKD-IRS2-v4 (IRS-2; Upstate) in the presence of FuGENE HD transfection reagent (Roche) as described in the Materials and methods. The expression of the type I IGF receptor, IRS-1 and IRS-2 was measured in the transfected MCF-7 and MDA-MB-231 cells following culture under the conditions used during preparation of the cells for the migration experiments, as described in the Materials and methods. The cells were lysed and protein extracts prepared as described in the Materials and methods. The amounts of the type I IGF receptor, IRS-1 and IRS-2 proteins were measured by western transfer analysis as described in the Materials and methods. Aliquots of $5 \mu \mathrm{g}$ protein were electrophoresed on gradient polyacrylamide gels and transferred to nitrocellulose

membranes. The membranes were incubated with a 1:3000 dilution of specific type I IGF receptor antibody (Cell Signalling, 3027), a 1:4000 dilution of specific IRS-1 antibody (Upstate, 06-248), a 1: 500 dilution of specific IRS-2 antibody (Santa Cruz, sc-1555-R) or a 1: 20000 dilution of specific GAPDH antibody (Santa Cruz, sc-25778) overnight at $4{ }^{\circ} \mathrm{C}$. The filters were washed and incubated with HRP-conjugated goat-anti-rabbit antibody and the proteins detected using enhanced chemiluminescence (Western Dura Super Signal extended duration substrate, Pierce).

described in the Materials and methods. Representative examples of the knockdown achieved in the cells after transfection and subsequent culture in the withdrawal medium prior to examination of the migratory response to IGF-1 are shown in Fig. 6. The migratory response to all concentrations of IGF-1 was reduced significantly in MDA-MB-231 and MCF-7 cells in which the endogenous expression of the type I IGF receptor had been lowered (Fig. 7). Decreased expression of endogenous IRS- 1 or IRS- 2 reduced migration stimulated by 11 and $100 \mathrm{ng} / \mathrm{ml}$ IGF-1 in MDA-MB-231 cells and by $100 \mathrm{ng} / \mathrm{ml}$ (13 nM) IGF-1 in MCF-7 cells (Fig. 7). The greater effect of reducing expression of the type I IGF receptor than either IRS-1 or IRS-2 led us to test the effect of decreasing the expression of IRS-1 and IRS-2 simultaneously. The stimulation of migration by different concentrations of IGF-1 was analysed in MCF-7 cells in which both IRS-1 and IRS-2 expression had been knocked down (Fig. 7C). There was a significant reduction in the migration stimulated by $3.5,11$ and $35 \mathrm{ng} / \mathrm{ml}$ IGF-1 $(0.45-4.55 \mathrm{nM})$ in cells with reduced IRS-1 and IRS-2 expression.

\section{Discussion}

The IGF signal transduction system has several properties that are compatible with a role in the progression of cancer. IGFs are mitogenic for many cell types, inhibit apoptosis and stimulate cell migration. These effects of IGFs on cancer cells are of increasing interest and are one of the reasons why the IGF signal transduction pathway has captured the imagination of the pharmaceutical industry as a therapeutic target for the treatment of cancer (Baserga 2004, Hofmann \& Garcia-Echeverria 2005, Sachdev \& Yee 2006).

Our results show that elevated expression of both IRS-1 and IRS-2 increases the sensitivity of the migration of both MCF-7 and MDA-MB-231 cells to lower IGF-1 concentrations but does not increase migration at higher IGF concentrations. This implies that IRS-1 and IRS-2 are important molecules in controlling breast cancer cell migration and invasion. The knockdown experiments demonstrate that IRS-1 and IRS-2 expressed by breast tumour cells contribute 
to the migratory response of the breast cancer cells, and reinforce the conclusions based on the experiments in which IRS-1 and IRS-2 expression is increased in breast cancer cells.

There have been very few studies on the pathways and molecules downstream of the type I IGF receptor that mediate cell migration and invasion. Bartucci
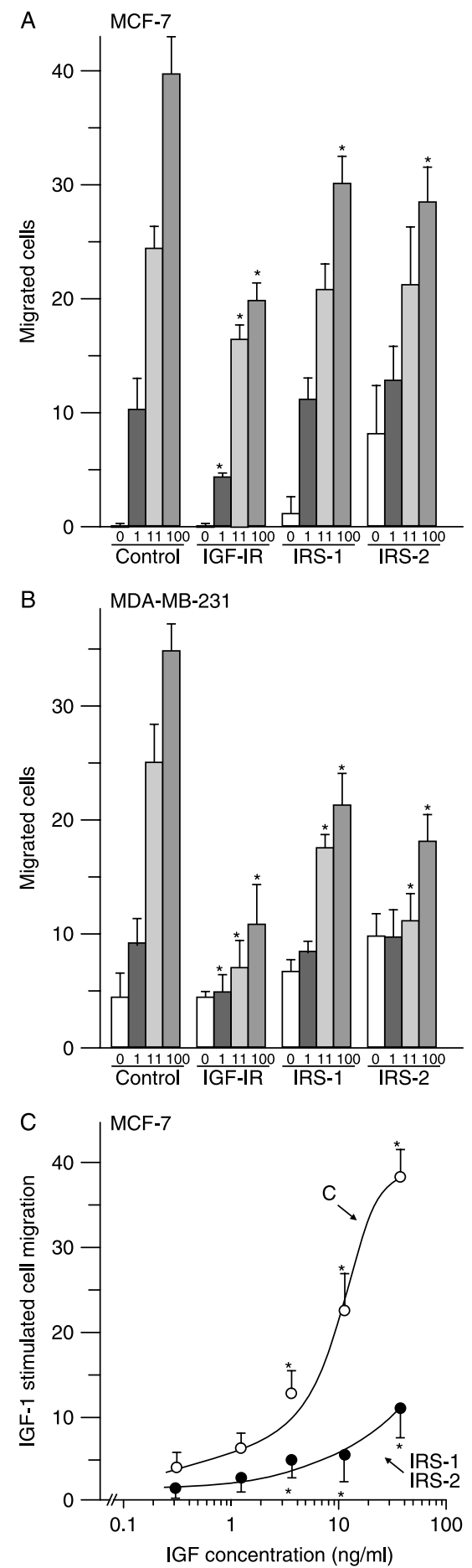

et al. (2001) implicated the PI3 kinase/Akt pathway, whereas Mira et al. (2001) have emphasised the role of cytokines and shown that IGF-1 increases expression of the cytokine CCL5 and causes a redistribution of its receptor CCR5 to the leading edge of migratory cells.

It is possible that the migratory effects of IGFs are mediated through IRS- 1 and IRS- 2 as these are immediate downstream signalling proteins from the type I IGF receptor and are phosphorylated rapidly following treatment of cells with IGF-1. Byron et al. (2006) have suggested recently that IRS-1 mediates the mitogenic effects of IGFs, whereas IRS-2 mediates the motogenic effects on the basis of experiments in which T47D cells that do not express IRS-1 or IRS-2 were transfected with IRS-1 and IRS-2 expression plasmids. These results differ from ours in that we find that higher expression of both IRS-1 and IRS-2 increases the migration of two breast cancer cell lines stimulated by lower IGF concentrations. Increased IRS-1 and IRS-2 did not, however, increase significantly cell migration stimulated by higher IGF-1 concentrations. The different conclusions may be attributed to one of the several factors including the use of different cell lines, different migration assays (Boyden chamber versus gold particle assay). More interestingly, they may result from the use of a single relatively high IGF-1 concentration by Byron et al. (2006), as at the concentration of $38.5 \mathrm{ng} / \mathrm{ml}(5 \mathrm{nM})$ IGF-1 used by these authors, we found near maximal stimulation of both untransfected and transfected cells. An alternative explanation is that IRS-1 requires the presence of IRS-2 to stimulate cell migration.

The observation that the amounts of both IRS- 1 and IRS-2 influence the sensitivity of cell migration to IGFs suggests that both of these proteins are present in amounts that limit the sensitivity of the response and are therefore the key proteins in the signal transduction

Figure 7 Effect of decreased expression of type I IGF receptor, IRS-1 and IRS-2 on IGF-1 stimulated cell migration in MCF-7 and MDA-MB-231 cells. MCF-7 (A and C) and MDA-MB-231 (B) cells were transfected with control vector or siRNA plasmids: pKD-IGF-IR-v2; pKD-IRS1-v3 or pKD-IRS2-v4 and the migration stimulated by different concentrations of IGF-1 between 0 and $100 \mathrm{ng} / \mathrm{ml}(0-13 \mathrm{nM})$ was measured in triplicate experiments as described in the Materials and methods. Migration of control transfected cells (control) and cells transfected with siRNA plasmids: pKD-IGF-IR-v2 (IGF-IR); pKD-IRS1-v3 (IRS-1) or pKD-IRS2-v4 (IRS-2) are shown ( $A$ and $B$ ). The bars show the S.E.M. Open circles show the migration stimulated by different concentrations of IGF-1 in control transfected cells and filled circles the migration of cells transfected with pKD-IRS1-v3 and pKD-IRS2-v4 (C). The bars show the S.E.M. Asterisks show the IGF-1 concentrations at which migration is statistically significantly lower in the cells transfected with the siRNA plasmids than in the control cells ( $t$-test, $P<0.05)$. 
pathway controlling the motogenic response to IGFs. It also suggests that these two proteins can substitute for each other in the pathway although their relative importance remains to be defined. Increasing the expression of IRS-1 and IRS-2 to very high levels may lead to super-sensitivity to IGFs which may be interpreted as IGF resistance in a similar way that antioestrogen resistant breast cancer cells have been reported to be exquisitely sensitive to low concentrations of oestrogen (Chan et al. 2002). We have reported previously that oestrogens increase the expression of the type I IGF receptor (Stewart et al. 1990) and that this alters the sensitivity of the proliferative response to IGF-1 but not the magnitude of the response (Daws et al. 1996). This observation is consistent with the view that type I IGF receptor levels as well as the levels of IRS-1 and IRS-2 are important in controlling cellular responses to IGF-1.

We have observed previously that oestrogen increases the expression of IRS-1 (Molloy et al. 2000) and have suggested that this may be the mechanism by which oestrogens increase the response of breast cancer cells to IGFs (Molloy et al. 2000). The observation that IRS-1 and IRS-2 are important in the migratory response to IGF-1 may suggest that oestrogens could contribute to tumour progression through their effects on IRS-1 and IRS-2 expression. IRS-1 may be as important as IRS-2 as although increased levels of IRS-2 have a more pronounced effect on the sensitivity of cell migration to IGF-1, oestrogen induces IRS-1 expression to a greater extent than IRS-2. The importance of IRS-1 and IRS-2 in mediating IGF stimulated migration is reinforced by the demonstration that their knockdown decreases the migration stimulated by IGF-1 in MCF-7 and MDAMB-231 cells. Taken together, our results suggest that the levels of endogenous expression of the type I IGF receptor, IRS-1 and IRS-2, which are regulated by oestrogen in oestrogen-responsive breast cancer cells, affect the motogenic response to IGFs. This implies that the increased expression induced in the presence of oestrogen will impact significantly on the invasive behaviour of breast tumour cells.

There is increasing interest in cancer treatments that reduce the establishment and growth of metastatic deposits and inhibitors of the IGF signal transduction pathway may be effective in this clinical setting. These inhibitors would complement other inhibitors that have been identified such as epidermal growth factor receptor (EGFR) tyrosine kinase inhibitors, which have proven effectiveness in a murine model of pulmonary metastasis of breast cancer (Choi et al. 2006), vascular endothelial growth factor (VEGF) inhibitors, which have been developed to inhibit vascularisation of secondary tumours (Mazitschek \& Giannis 2004), and CXCR4 inhibitors, which inhibit the migratory effects of CXCL12 (Lee et al. 2004).

Inhibitors of the IGF system, all of which target the type I IGF receptor, have now reached the stage of clinical evaluation. The strategies used to date include neutralising antibodies, dominant negative receptor mutants, inhibitors of autophosphorylation and protein tyrosine kinase activity. There have been no reports of agents targeted against IRS proteins, apart from dominant negative mutants that lack the carboxyterminus (Tanaka \& Wands 1996) or all tyrosine residues (White 2002). Inhibitors of IRS-1 and IRS-2 may refine the specificity and reduce the side effects of IGF targeted therapy.

In conclusion, both IRS-1 and IRS-2 levels control the migratory response of breast cancer cells to IGF-1 and may, therefore, be key molecules in determining breast cancer spread. The IRS proteins may be at the convergence point of the effects of oestrogens and IGFs on cell proliferation and migration and could be therapeutic targets in oestrogen-responsive and nonresponsive breast cancer cells.

\section{Declaration of interest}

The authors declare that there is no conflict of interest that could be perceived as prejudicing the impartiality of the research reported.

\section{Funding}

This research was supported by the Breast Cencer Campaign grant numbers 1999:88 and 2003:737. We thank the Breast Cancer Campaign for funding this work.

\section{Acknowledgements}

We thank the Breast Cancer Campaign for funding this work; grant numbers 1999:88 and 2003:737. We thank Dr C R Kahn, Joslin Diabetes Centre, Department of Medicine, Harvard Medical School, Boston, Massachusetts 02215 for the IRS-1 plasmid and Dr L Klein-Hitpass, University of Essen, FRG for the IRS-2 plasmids.

\section{References}

Altundag K \& Ibrahim NK 2006 Aromatase inhibitors in breast cancer: an overview. Oncologist 11 553-562.

Bae SN, Arand G, Azzam H, Pavasant P, Torri J, Frandsen TL \& Thompson EW 1993 Molecular and cellular analysis of basement membrane invasion by human breast cancer cells in matrigel-based in vitro assays. Breast Cancer Research and Treatment 24 241-255. 
Bartucci M, Morelli C, Mauro L, Ando S \& Surmacz E 2001 Differential insulin-like growth factor I receptor signaling and function in estrogen receptor (ER)-positive MCF-7 and ER-negative MDA-MB-231 breast cancer cells. Cancer Research 61 6747-6754.

Baserga R 2004 Targeting the IGF-1 receptor: from rags to riches. European Journal of Cancer 40 2013-2015.

Bernard L, Legay C, Adriaenssens E, Mougel A \& Ricort JM 2006 Estradiol regulates the insulin-like growth factor-I (IGF-I) signalling pathway: a crucial role of phosphatidylinositol 3-kinase (PI 3-kinase) in estrogens requirement for growth of MCF-7 human breast carcinoma cells. Biochemical and Biophysical Research Communications 350 916-921.

Byron SA, Horwitz KB, Richer JK, Lange CA, Zhang X \& Yee D 2006 Insulin receptor substrates mediate distinct biological responses to insulin-like growth factor receptor activation in breast cancer cells. British Journal of Cancer 95 1220-1228.

Chan JM, Stampfer MJ, Giovannucci E, Gann PH, Ma J, Wilkinson P, Hennekens CH \& Pollak M 1998 Plasma insulin-like growth factor-I and prostate cancer risk: a prospective study. Science 279 563-566.

Chan CM, Martin LA, Johnston SR, Ali S \& Dowsett M 2002 Molecular changes associated with the acquisition of oestrogen hypersensitivity in MCF-7 breast cancer cells on long-term oestrogen deprivation. Journal of Steroid Biochemistry and Molecular Biology 81 333-341.

Chang Q, Li Y, White MF, Fletcher JA \& Xiao S 2002 Constitutive activation of insulin receptor substrate 1 is a frequent event in human tumors: therapeutic implications. Cancer Research 62 6035-6038.

Choi YJ, Nam SJ, Son MJ, Kim DK, Kim JH, Yang JH, Kim MH, Song HS, Nam DH \& Bang SI 2006 Erlotinib prevents pulmonary metastasis in curatively resected breast carcinoma using a mouse model. Oncology Reports 16 119-122.

Clayton SJ, May FEB \& Westley BR 1997 IGFs control the regulation of oestrogen and progesterone receptor by oestrogens. Molecular and Cellular Endocrinology 128 57-68.

D'Ambrosio C, Keller SR, Morrione A, Lienhard GE, Baserga R \& Surmacz E 1995 Transforming potential of the insulin receptor substrate 1. Cell Growth and Differentiation 6 557-562.

Davies M, Gupta S, Goldspink G \& Winslet M 2006 The insulin-like growth factor system and colorectal cancer: clinical and experimental evidence. International Journal of Colorectal Disease 21 201-208.

Daws MR, Westley BR \& May FEB 1996 Paradoxical effects of overexpression of the type I insulin-like growth factor (IGF) receptor on the responsiveness of human breast cancer cells to IGFs and estradiol. Endocrinology 137 1177-1186.

Doerr ME \& Jones JI 1996 The roles of integrins and extracellular matrix proteins in the insulin-like growth factor I-stimulated chemotaxis of human breast cancer cells. Journal of Biological Chemistry 271 2443-2447.

Donaghue C, Westley BR \& May FEB 1999 Selective promoter usage of the human estrogen receptor gene and its regulation by estrogen. Molecular Endocrinology 13 1934-1950.

Eliassen AH, Missmer SA, Tworoger SS, Spiegelman D, Barbieri RL, Dowsett M \& Hankinson SE 2006

Endogenous steroid hormone concentrations and risk of breast cancer among premenopausal women. Journal of the National Cancer Institute 98 1406-1415.

Gibson SL, Ma Z \& Shaw LM 2007 Divergent roles for IRS-1 and IRS-2 in breast cancer metastasis. Cell Cycle $\mathbf{6}$ 631-637.

Guvakova MA \& Surmacz E 1997 Overexpressed IGF-I receptors reduce estrogen growth requirements, enhance survival, and promote E-cadherin-mediated cell-cell adhesion in human breast cancer cells. Experimental Cell Research 231 149-162.

Hailey J, Maxwell E, Koukouras K, Bishop WR, Pachter JA \& Wang Y 2002 Neutralizing anti-insulin-like growth factor receptor 1 antibodies inhibit receptor function and induce receptor degradation in tumor cells. Molecular Cancer Therapeutics 1 1349-1353.

Hankinson SE, Willett WC, Colditz GA, Hunter DJ, Michaud DS, Deroo B, Rosner B, Speizer FE \& Pollak M 1998 Circulating concentrations of insulin-like growth factor-I and risk of breast cancer. Lancet 351 1393-1396.

Hofmann F \& Garcia-Echeverria C 2005 Blocking the insulin-like growth factor-I receptor as a strategy for targeting cancer. Drug Discovery Today 10 1041-1047.

Jackson JG, Zhang X, Yoneda T \& Yee D 2001 Regulation of breast cancer cell motility by insulin receptor substrate-2 (IRS-2) in metastatic variants of human breast cancer cell lines. Oncogene 20 7318-7325.

Kooijman R 2006 Regulation of apoptosis by insulin-like growth factor (IGF)-I. Cytokine and Growth Factor Reviews 17 305-323.

Lee AV, Jackson JG, Gooch JL, Hilsenbeck SG, CoronadoHeinsohn E, Osborne CK \& Yee D 1999 Enhancement of insulin-like growth factor signaling in human breast cancer: estrogen regulation of insulin receptor substrate-1 expression in vitro and in vivo. Molecular Endocrinology 13 787-796.

Lee BC, Lee TH, Avraham S \& Avraham HK 2004 Involvement of the chemokine receptor CXCR4 and its ligand stromal cell-derived factor 1alpha in breast cancer cell migration through human brain microvascular endothelial cells. Molecular Cancer Research 2 327-338.

Li SL, Liang SJ, Guo N, Wu AM \& Fujita-Yamaguchi Y 2000 Single-chain antibodies against human insulin-like growth factor I receptor: expression, purification, and effect on tumor growth. Cancer Immunology and Immunotherapy 49 243-252.

Maloney EK, McLaughlin JL, Dagdigian NE, Garrett LM, Connors KM, Zhou XM, Blattler WA, Chittenden T \& 
Singh R 2003 An anti-insulin-like growth factor I receptor antibody that is a potent inhibitor of cancer cell proliferation. Cancer Research 63 5073-5083.

Mauro L, Salerno M, Panno ML, Bellizzi D, Sisci D, Miglietta A, Surmacz E \& Ando S 2001 Estradiol increases IRS-1 gene expression and insulin signaling in breast cancer cells. Biochemical and Biophysical Research Communications 288 685-689.

Mazitschek R \& Giannis A 2004 Inhibitors of angiogenesis and cancer-related receptor tyrosine kinases. Current Opinion in Chemical Biology 8 432-441.

Mira E, Lacalle RA, Gonzalez MA, Gomez-Mouton C, Abad JL, Bernad A, Martinez AC \& Manes S 2001 A role for chemokine receptor transactivation in growth factor signaling. EMBO Reports 2 151-156.

Molloy CA, May FEB \& Westley BR 2000 Insulin receptor substrate-1 expression is regulated by estrogen in the MCF-7 human breast cancer cell line. Journal of Biological Chemistry 275 12565-12571.

Pandini G, Vigneri R, Costantino A, Frasca F, Ippolito A, Fujita-Yamaguchi Y, Siddle K, Goldfine ID \& Belfiore A 1999 Insulin and insulin-like growth factor-I (IGF-I) receptor overexpression in breast cancers leads to insulin/IGF-I hybrid receptor overexpression: evidence for a second mechanism of IGF-I signaling. Clinical Cancer Research 5 1935-1944.

Pennisi PA, Barr V, Nunez NP, Stannard B \& Le Roith D 2002 Reduced expression of insulin-like growth factor I receptors in MCF-7 breast cancer cells leads to a more metastatic phenotype. Cancer Research 62 6529-6537.

Peruzzi F, Prisco M, Dews M, Salomoni P, Grassilli E, Romano G, Calabretta B \& Baserga R 1999 Multiple signaling pathways of the insulin-like growth factor 1 receptor in protection from apoptosis. Molecular and Cellular Biology 19 7203-7215.

Pollak M 2000 Insulin-like growth factor physiology and cancer risk. European Journal of Cancer 36 1224-1228.

Prest SJ, May FEB \& Westley BR 2002 The estrogenregulated protein, TFF1, stimulates migration of human breast cancer cells. FASEB Journal 16 592-594.

Rocha RL, Hilsenbeck SG, Jackson JG, VanDenBerg CL, Weng C, Lee AV \& Yee D 1997 Insulin-like growth factor binding protein-3 and insulin receptor substrate-1 in breast cancer: correlation with clinical parameters and diseasefree survival. Clinical Cancer Research 3 103-109.

Sachdev D \& Yee D 2001 The IGF system and breast cancer. Endocrine-Related Cancer 8 197-209.

Sachdev D \& Yee D 2006 Inhibitors of insulin-like growth factor signaling: a therapeutic approach for breast cancer. Journal of Mammary Gland Biology and Neoplasia 11 27-39.

Sachdev D, Li SL, Hartell JS, Fujita-Yamaguchi Y, Miller JS \& Yee D 2003 A chimeric humanized single-chain antibody against the type I insulin-like growth factor (IGF) receptor renders breast cancer cells refractory to the mitogenic effects of IGF-I. Cancer Research 63 $627-635$.
Schernhammer ES, Holly JM, Pollak MN \& Hankinson SE 2005 Circulating levels of insulin-like growth factors, their binding proteins, and breast cancer risk. Cancer Epidemiology, Biomarkers and Prevention 14 699-704.

Stewart AJ, Johnson MD, May FEB \& Westley BR 1990 Role of insulin-like growth factors and the type I insulinlike growth factor receptor in the estrogen-stimulated proliferation of human breast cancer cells. Journal of Biological Chemistry 265 21172-21178.

Stromberg T, Ekman S, Girnita L, Dimberg LY, Larsson O, Axelson M, Lennartsson J, Hellman U, Carlson K, Osterborg A et al. 2006 IGF-1 receptor tyrosine kinase inhibition by the cyclolignan PPP induces G2/M-phase accumulation and apoptosis in multiple myeloma cells. Blood 107 669-678.

Sun XJ, Rothenberg P, Kahn CR, Backer JM, Araki E, Wilden PA, Cahill DA, Goldstein BJ \& White MF 1991 Structure of the insulin receptor substrate IRS-1 defines a unique signal transduction protein. Nature 352 73-77.

Tanaka S \& Wands JR 1996 A carboxy-terminal truncated insulin receptor substrate- 1 dominant negative protein reverses the human hepatocellular carcinoma malignant phenotype. Journal of Clinical Investigation 98 2100-2108.

Tazzari PL, Tabellini G, Bortul R, Papa V, Evangelisti C, Grafone T, Martinelli G, McCubrey JA \& Martelli AM 2007 The insulin-like growth factor-I receptor kinase inhibitor NVP-AEW541 induces apoptosis in acute myeloid leukemia cells exhibiting autocrine insulin-like growth factor-I secretion. Leukemia 21 886-896.

Vassen L, Wegrzyn W \& Klein-Hitpass L 1999 Human insulin receptor substrate-2: gene organization and promoter characterization. Diabetes 48 1877-1880.

Wang Y, Hailey J, Williams D, Wang Y, Lipari P, Malkowski M, Wang X, Xie L, Li G, Saha D et al. 2005 Inhibition of insulin-like growth factor-I receptor (IGF-IR) signaling and tumor cell growth by a fully human neutralizing anti-IGF-IR antibody. Molecular Cancer Therapeutics 4 1214-1221.

Westley BR \& May FEB 2006 Identification of steroid hormone regulated genes in breast cancer. Methods in Molecular Medicine 120 363-388.

Westley BR, Clayton SJ, Daws MR, Molloy CA \& May FEB 1998 Interactions between the oestrogen and insulin-like growth factor signalling pathways in the control of breast epithelial cell proliferation. Biochemical Society Symposium 63 35-44.

White MF 2002 IRS proteins and the common path to diabetes. American Journal of Physiology 283 E413-E422.

Wickerham L 2002 Tamoxifen - an update on current data and where it can now be used. Breast Cancer Research and Treatment 75 S7-S12.

Yee D 2006 Targeting insulin-like growth factor pathways. British Journal of Cancer 94 465-468. 